\title{
A Paracelsian Parallel: Conrad Gessner on Medical Alchemy
}

Gantenbein, Urs Leo

DOI: https://doi.org/10.1515/9783110499056-014

Posted at the Zurich Open Repository and Archive, University of Zurich

ZORA URL: https://doi.org/10.5167/uzh-181468

Book Section

Published Version

Originally published at:

Gantenbein, Urs Leo (2019). A Paracelsian Parallel: Conrad Gessner on Medical Alchemy. In: Leu, Urs; Opitz, Peter. Conrad Gessner (1516-1565) : Die Renaissance der Wissenschaften / The Renaissance of Learning. Berlin/Boston: Walter de Gruyter, 273-294.

DOI: https://doi.org/10.1515/9783110499056-014 


\section{Conrad Gessner (1516-1565)}

Die Renaissance der Wissenschaften/

The Renaissance of Learning

Herausgegeben von/Edited by Urs. B. Leu und/and Peter Opitz 
ISBN 978-3-11-049696-3

e-ISBN (PDF) 978-3-11-049905-6

e-ISBN (EPUB) 978-3-11-049592-8

Library of Congress Control Number: 2019936230

Bibliografische Information der Deutschen Nationalbibliothek

Die Deutsche Nationalbibliothek verzeichnet diese Publikation in der Deutschen

Nationalbibliografie; detaillierte bibliografische Daten sind im Internet

über http://dnb.dnb.de abrufbar.

(C) 2019 Walter de Gruyter GmbH, Berlin/Boston

Umschlagabbildung/Cover Image: Grosshans Thomann: Conradus Gesnerus Tigurinus medicus et philosophiae interpres anno aetatis suae XLVIII anno salutis MDLXIIII nonis martis, 1564 (ZBZ, Graphische Sammlung und Fotoarchiv).

Satz: Meta Systems Publishing \& Printservices GmbH, Wustermark

Druck und Bindung: CPI books GmbH, Leck

www.degruyter.com 


\section{Urs Leo Gantenbein}

\section{A Paracelsian Parallel: Conrad Gessner on Medical Alchemy}

\section{Prologue: Gessner versus Paracelsus}

When in 1552 Conrad Gessner was publishing his Thesaurus Euonymus Philiatri, he was standing on the same centuries-old tradition of medical alchemy as his fellow countryman Theophrastus of Hohenheim, called Paracelsus (1493/94-1541). ${ }^{1}$ While late Greek and medieval alchemy was mainly preoccupied with the transmutation of metals and speculative theories about creation and the generation of things, the aim of medical alchemy was to refine pharmaceutical raw materials by way of distillation or chemical reactions. In this sense, Paracelsus and his followers were commonly regarded as the founders of a new medicinal therapy based on processed remedies like tinctures, elixirs, quintae essentiae, arcana, and magisteria, whereas the ancient and medieval physicians were solely using raw substances and mixtures of them. In fact, medical alchemy originates in the Early Middle Ages and is reflected in numerous manuscripts and early prints. ${ }^{2}$ As was his custom, Gessner meticulously collected every reference to alchemically prepared drugs he could find and incorporated them into his Thesaurus. Although at that time Paracelsus and his reform of medicine on alchemical grounds were well known in Zurich, Gessner for certain reasons did not explicitly mention him.

Since Gessner was a literate polymath in the humanistic tradition with fluent knowledge of the ancient languages, his medicine was based on Hippocrates, Galen, Avicenna, and Mesue, and his view of nature rested on Aristotle and Pliny. In this sense he was extremely skeptical towards "empiricists" who rather relied on practical experience. The ideals of Paracelsus were quite the opposite. In Italy he had graduated in medicine and surgery. Trained in practical alchemy, he was accustomed to observe nature and to trust in personal experience rather than in mere book knowledge. He relied on the "separatio puri ab impuro", the separation of the pure essence from an otherwise toxic substance, which constituted a basic principle of medical alchemy formulated by John of Rupescissa (14th century). He knew Latin

1 On Paracelsus's stay in Zurich in 1527 and Gessner's relation to him see also Fischer (1966), pp. 87-89; Leu (2016), pp. 313-317; Webster (1990). The statements in Fischer (1967), pp. 39-47, Milt (1929), pp. 486-488, 506-509, and Milt (1941), pp. 321-354, should be reviewed before used, since they are mostly not referenced.

2 On the history of medical alchemy and its role as a source of Paracelsus see Halleux (1979), Gantenbein (2011), and Kahn (2016).

Urs Leo Gantenbein, Institute of Evolutionary Medicine, University of Zurich, Zurich, Switzerland, e-mail: ursleo.gantenbein@paracelsus-project.org

https://doi.org/10.1515/9783110499056-014 
well enough to read, but preferred to write and lecture in German. When in 1527 Paracelsus became professor of medicine in Basle, he distributed a handbill to announce his bold reform. He promised to eradicate the common medical errors and proposed a medicine founded on pure natural experience and not on the doctrines of Hippocrates, Galen and Avicenna. Instead he held out the prospect of teaching medicine and surgery based on books written by himself. Later on, in the book Paragranum (1530), he formulated his famous four pillars of medicine consisting of philosophy, astronomy, alchemy, and virtue. ${ }^{3}$ In this scheme, philosophy expounds the natural laws and substances which are relevant for medical therapy; astronomy describes the secret bonds between heaven and the earthly things; alchemy teaches the true preparation of remedies; and virtue stands for the medical ethics and right attitude of the physician. As elucidated in the Opus Paramirum (1531), the principles of alchemy extend to the human body in order to describe the functioning of the organs. Integrating alchemy into his system of medicine, Paracelsus above all excelled in the formulation of new theories. ${ }^{4}$ As a radical religious reformer, he was also engaged in the theological debate of his time. ${ }^{5}$ His idiosyncratic views on true Christian life, the Eucharist, and redemption aroused even more suspicion among the Zurich clergy. Not only the foundations of medicine were in danger, but also the very achievements of Protestant Reformation. When in 1527 the Zurich theologian and later church leader Heinrich Bullinger (1504-1575) discussed with Paracelsus religious matters, he was disgusted and reported that he saw in Paracelsus no sign of piety, but much of a self-made magic. ${ }^{6}$ Bullinger was Gessner's highly respected mentor who had made possible his foreign studies. It would have been an unacceptable affront to Bullinger to give Paracelsus any credit. There was still another person in Zurich to whom Gessner had to pay respect, namely the Zurich town physician Christoph Clauser (ca 1490-1552). ${ }^{7}$ He too was prejudiced against Paracelsus, although the two men had much in common. Both had received their doctoral degree in Ferrara at roughly the same time, both wrote astrological prognostications, and both were interested in medical alchemy. Clauser possessed many relevant alchemical manuscripts. ${ }^{8}$ Moreover, as the son of the Zurich pharmacist Anton Clauser, he must have been acquainted early on with distillation procedures. ${ }^{9}$ After meeting Christoph Clauser in Zurich, Paracelsus sent him in autumn 1527 the Latin manuscript of his treatise De gradibus et compositionibus receptorum et naturalium [On the grades and compositions of simple natural substances], with the objective of revising Galen's system of grades in the light of empirical knowledge based on al-

\footnotetext{
3 Paracelsus (2008), pp. 43-44, 75.

4 Paracelsus (2008), pp. 1-59.

5 The theological works are edited in the New Paracelsus Edition, see www.paracelsus.uzh.ch.

6 Erastus (1571), pp. 239-240.

7 On Clauser see Wehrli (1924), Milt (1941), pp. 322-325, Gantenbein (2008), and Müller (2016).

8 Heyne (2002).

9 Gantenbein (2007).
} 
chemy. Paracelsus wanted to have it printed in Zurich, but Clauser must have been utterly alarmed when reading the accompanying letter: "I have an innate medical impetuosity [violentia] originating from my fatherland. Just as the physician of the Arabs was Avicenna, of the people of Pergamon Galen, and as the best physician of the Italians was indeed Marsilius Ficinus, so in the very same way most blessed Germany has appointed me as her necessary physician. You know yourself that the mother of every physician is experience ... Every nation produces her proper and particular physician ... As the Greeks differ from the Italians and the Germans from both, so do they all have their necessity, and out of this necessity they all have their own helper, according to the nation's nature. When someone strives after the achievements and morals of the Arabs or Greeks, then this is no necessity, but rather means an error and a foreign arrogance towards the fatherland." 10 Undoubtedly, Paracelsus was endowed with a sense of mission and saw himself as the great reformer of medicine, but these lines reveal a rather inflated self-esteem which was certainly not appreciated by his contemporaries. Even worse, scholarly medicine with its dependence on the ancient authors, was shaken to its very foundations, and therefore it is not surprising that Clauser did not respond to the request. On the contrary, in the popular 1531 dialogue on uroscopy he tried to discredit him. Here he used the nickname "Thessalus" which Paracelsus was given in Basle, referring to the Roman physician Thessalus of Tralles who was considered a quack: "Midwife: The Luther of the physicians has lectured in Basle at the university where he has publicly rejected all the ancient writers of medicine ... Doctor: That ... Thessalus of Hohenheim is not unknown to me, but I do not know whether he has the knowledge of nature. He knows several things, namely in surgery, but he knows even more in the sophistry of alchemy. I have also met him. What he has done in Basle was a great folly and ignorance." 11 This passage confirms that Clauser totally rejected the Basle reform. He acknowledged that Paracelsus had some knowledge in surgery and alchemy, but the former was considered a lesser and the latter even a dubious art in contrast to noble medicine. In Clauser's eyes, Paracelsus was at best a skilled barber-surgeon, but never a physician. So Gessner's mostly negative view of Paracelsus was strongly influenced by the opinions of his two close friends and mentors, Bullinger and Clauser, to whom he owed a great debt of gratitude. This is clearly reflected in the entry on Paracelsus in the Bibliotheca universalis (1545). Here Gessner writes that he had seen a copy of the handbill advertising the Basle courses, and adds that Paracelsus had lectured in German because he did not know Latin. Then Gessner reports having seen Paracelsus's manuscript of De gradibus et compositionibus in the Clauser library, which he judged as "in all its dictions and sentences obscure, barbaric, affected, inept”. ${ }^{12}$ Some ten years later, in De chirurgia scrip-

10 Paracelsus/Huser, vol. 7, f. Vv-VIr, partly translated into German in Milt (1941), pp. 324-325.

11 Clauser (1531), f. $B_{2} v^{\prime \prime} A_{t}-B_{3} r$.

12 Gessner (1545), f. 614v. 
tores (1555), Gessner's image of Paracelsus was much more differentiated. Now there is already the ambiguous mixture of condemnation and admiration that is also typical for his subsequent mentionings of Paracelsus, on one hand the accusation of being a drinker and magician, on the other a respectful recognition of his healing successes: "Theophrastus Paracelsus had lived in our time. Thoroughly contemptible of the ancients, he had tried to introduce entirely new things into the art of medicine. He practiced medicine as a vagabond in diverse regions of Switzerland, Germany, and Poland. He usually had no money, and as soon as he got some, he spent it for wine and gambling ... thus healing nobody. He used a familiar demon, as I have heard of his disciple ... He was utterly inconstant, now a theologian, now a physician, now a magician, often a fellow drinker and a dice-player with the peasants. Yet I hear that everywhere he had cured many from desperate diseases and that he had happily healed bad ulcers. In fact, he was experienced in the chemical art and prepared liquors, potions, oils (especially of antimony) and many other wonderful medicaments."13

It is interesting to note that Gessner here, three years after the first edition of the Thesaurus, finally acknowledged Paracelsus's achievements in medical alchemy. His special emphasis of antimony, in fact being mineral antimony trioxide, casts a new light on a passage in the Thesaurus where Gessner treats the preparations of this mineral. After briefly listing the prescriptions of Mattioli and Ulstad, which were meant for the treatment of difficult wounds, Gessner goes on to add a somewhat longer section with further modes of preparation. ${ }^{14}$ He mentions "certain empiricists" who know to prepare an oil of antimony with additional marvelous curative effects in internal ailments. In the first formula, antimony and calcined tartar are mixed, heated and liquified in a crucible. The cooled melt is crushed, put into a conical filter which is suspended in a humid place. Then the blood-red oil of antimony drops into the receptacle which is made ready beneath. To extract the intended medicinal quintessence, the oil is mixed with "quinta essentia vini vel aqua ardente" [distilled alcohol] and then distilled three or four times. Gessner continues and gives yet another technique which he had received, as he writes, from another "empiricus", equaling a travelling physician. ${ }^{15}$ In this formula, antimony, calcined tartar, and distilled vinegar are mixed together right from the beginning and then distilled without first producing the red oil of antimony. Exactly the same preparations were taught by Paracelsus in his Basle lectures as is documented in the following short students' notes: "Ad omina vulnera, distillatio: Rec. tartari calcinati, antimonii ana drach. 4; reduc in flores, superfunde vini ardentis drach. sem. et distilla per alembicum." 16 [For all wounds, a distillation: Take calcined tartar and

13 Gessner (1555c), f. 408r; the English translation is taken from Gantenbein (2013), p. 111.

14 Gessner (1552), pp. 411-414.

15 The German translation of the Thesaurus offers for "empiricus" the term "landfarender artzet", see e.g. Gessner (1555d), p. 283.

16 Paracelsus/Huser, vol. 7, p. 359. 
antimony each 4 drachmas; reduce to powder, pour over ardent wine half a drachma and distill by alembic.]

R. Antimonii lib. 1, tartari de vino albo libram sem., aceti destillati lib. 6; fiat destillatio in balneo Mariae per horas sex vel septem. dosis uncia una ad unc. 3, semel in die, et si non tollit icteritiam, lepra est. ${ }^{17}$

[Take antimony 1 pound, tartar of white wine half a pound, distilled vinegar 6 pounds; distill in the water bath for six or seven hours. The dose is 1 to 3 ounces once a day, and if the jaundice is not taken away, then it is leprosy.]

These two prescriptions from the Basle lectures are obviously identical with the ones in the Thesaurus. There are the same ingredients and roughly the same procedures, with the difference that Gessner is more elaborate in the technical details. Gessner may have obtained the formulas from a Paracelsian, possibly even from a former Basle student. There is another suspicious passage in the Thesaurus. Again Gessner reports about an "empiricus quidam" who used chemically prepared vitriol oil [sulfuric acid] in various diseases with great success. ${ }^{18}$ Also here it can be assumed that he meant Paracelsus who had written about the healing power of this substance, or at least a follower of him.

The image of Paracelsus that began to form in De chirurgia scriptores is continued in Gessner's correspondence. ${ }^{19}$ In a letter to the Strasbourg physician Didymus Obrecht of March 18, 1560, although referring to Paracelsus as a magician, Gessner even shows some national pride for his countryman who was born not far from Zurich. He admits that Paracelsus was most excellent in the chemical art and that he quickly cured chronic diseases which were otherwise held incurable. ${ }^{20}$ Principally rejecting magic, Gessner was at least in his early years willing to discuss it carefully when it was presented in a scholarly way. This can be seen from the long and respectful entries in the Bibliotheca universalis dedicated to Johannes Trithemius and Agrippa of Nettesheim. ${ }^{21}$ Whatever the topic, he accepted an author even more when he cultivated an eloquent and elegant Latin style, and with Paracelsus exactly the opposite was the case. Certainly Gessner was not completely wrong when he judged Paracelsus a magician who apparently sometimes resorted to magical practices. For example, the St. Gall chronicler Johannes Rütiner reports in 1534 that three years ago Paracelsus was caught when he had treated a patient with chiromantic characters in order to invoke a demon. ${ }^{22}$ The use of "characters," names and formu-

17 Paracelsus/Huser, vol. 3, p. 352.

18 Gessner (1552), p. 428.

19 See also Fischer (1966), pp. 87-89, Gantenbein (2013), pp. 98, 111-113, and Leu (2016), pp. 313317.

20 Gessner (1577), f. 114v.

21 Gessner (1545), f. 458v-459v and f. 307r-309v.

22 The patient was the St. Gall mayor Christian Studer, see Rütiner (1996), p. 205. 
las endowed with magical powers, was indeed part of Paracelsus's system of magical medicine. Possibly guessing the effects of psychotherapeutic coaxing or hypnosis, he stated that "words, pronounced or written, have the power against all diseases", and that they exert just the same healing power like herbs or other remedies. ${ }^{23}$ Furthermore, it can be shown that the concept of "gabalia" or "gaballistica" which appears in several works of Paracelsus, comes very close to the magical abilities described by Trithemius in this famous letter to Arnold Bostius of $1499 .{ }^{24}$ "Gabalia" in the sense of Paracelsus detects or determines the secret properties of natural things near and far. For both Trithemius and Paracelsus, these magical effects had nothing to do with witchcraft or sorcery, but were rather the expression of secret laws inherent in nature. These topics akin to Paracelsian, thought together with a world view of interdependent secret forces between the skies and earth, are generally represented by neo-Platonism and Italian Renaissance philosophy. Here also Gessner paid tribute to its main representative Marsilio Ficino, of whom he adds in the Bibliotheca universalis "several very bright works written in ornate language". 25 Of course, Gessner's own methodical approach was based on the more pragmatic Aristotelian natural philosophy, but he did not object to differing views when they were presented in a scholarly way. And in the same vein, although he himself did not deal with astrology, he allowed his medical colleagues to cast annual astrological prognostications to improve their income. This was an old tradition among physicians, and for example the universities of Vienna and Bologna even held chairs of astrology for this purpose. Paracelsus had written several prognostications, and the same was true for Gessner's predecessor and successor, Christoph Clauser and Caspar Wolf.

Now one may ask what was Gessner's main criticism of Paracelsus? As we have seen, it was not alchemy and not astrology. It was the very foundations of medicine that Gessner increasingly saw endangered. The above citations taken from De chirurgia scriptores (1555) and the letter to Obrecht of 1560 might suggest a slightly growing acceptance of Paracelsus. Before then, only very few of his works were publicly accessible, but exactly in 1560 the scene began to change dramatically. One writing of Paracelsus after the other went into print, and so until Gessner's death in 1565 there was a total number of thirty-four editions. When hitherto Paracelsian thought was more or less known only by hearsay, now the whole impact of his teachings began to dawn. So Gessner reacted alarmed when he read the newly printed De duplice anatomia of Paracelsus, which in 1561 Adam of Bodenstein had published in Basle. Sudhoff pointed out that this publication was a free Latin translation of the second book of a treatise on the various pathological effects of syphilis Paracelsus had written in 1528 in Colmar called Von Frantzösichen Blatern Lähme

23 Paracelsus/Huser, vol. 10, pp. 70, 464-465.

24 Gantenbein (2013), pp. 99-103.

25 Gessner (1545), f. 499r. 
Beulen Löchern/ vnd Zittrachten/ der Frantzosen vnd jhrs gleichen ... Zehen schöne Bücher [Of French blisters, bumps, palsy, lesions, and rashes of the French disease and the like ... ten beautiful books]. ${ }^{26}$ Here Paracelsus ridicules the anatomy of dead bodies and favors instead an essential anatomy describing the invisible places of disease in the human body. This more important microcosmic anatomy correlates to the macrocosmic stars and cannot be detected in the dissecting room. Again, Paracelsus does not hold back in his criticism of Avicenna and Galen. As is evident from his letter to the imperial physician Johannes Crato von Krafftheim (1519-1585) of August 16, 1561, Gessner was shocked by the statements in De duplice anatomia. ${ }^{27}$ Reinforcing his resistance with what was most powerful during the times of whichhunting, accusations of sorcery, and heresy, he appealed to Crato to come to the rescue: "And I know also other Paracelsians who scatter such writings wherein they apparently negate the divinity of Christ. This Theophrastus was an Arian, this is absolutely certain for me. Those act as if Christ were a totally nude man and pretend that in him was nothing else than in us ... For this reason and in order to truly preserve our foundations and method pursuant to Hippocrates and Galen, I urgently beseech you, most learned Sir, that you by all means oppose these intriguers, magicians, and Arians."28

Even worse for Paracelsus's reputation, in the same letter Gessner blamed him as a descendant of the magical school of Salamanca which had established the tradition of the travelling scholars to which also Faustus had belonged. ${ }^{29}$ It was this mixing with the saga of Faustus that proved really devastating. After the publication of the letter in 1577, this passage about Paracelsus and Faustus was cited over and over until the eighteenth century in order to substantiate the prejudices against Paracelsian philosophy and medicine. ${ }^{30}$

\section{The first Thesaurus of 1552}

The Thesaurus Euonymi Philiatri de remediis secretis (1552) was one of Gessner's most successful books. ${ }^{31}$ It was translated into several languages and went through numerous editions. Whether intentionally or not, the combination of an anonymous mysteriously named author with the prospect of a rich treasure trove of formulas for secret remedies proofed to be definitely tempting in the eyes of the readers. Already the front page promises a "physical, medical and partly chemical and eco-

26 Sudhoff (1894), pp. 63-64; Paracelsus (1605), pp. 249, 259-265.

27 For an overview of the anti-Paracelsian debate see Walter (2012).

28 Gessner (1577), f. 2r; the English translation is partly taken from Gantenbein (2013), p. 112.

29 Gessner (1577), f. $1 \mathrm{v}$.

30 Gantenbein (2013), pp. 98-99.

31 On the Thesaurus see also Dobler (1955), Büchi (1984), pp. 131-147; Leu (2016), pp. 309-313; Müller (2016), pp. 106-109. 
nomical book for physicians and pharmacists on how to produce wines of diverse flavors". However, the original intention was rather innocent. While the conventional preparation of pharmaceuticals relied on mechanical mixing of simple drugs, there was a century-old tradition of refining raw drugs by means of distillation, sublimation, or similar techniques. Since 1500 several prints dealing with the subject were published. As was his custom as a scholar, Gessner now wanted to give a synthesis of all he could find, be it printed, handwritten, or even orally transmitted. The self-invented author name "euonymus philiater" was a riddle itself. Starting from the Greek word elements "eu” (good, auspicious), "onyma” (name), "philos" (friend, lover), and "iatros" (physician), one could translate it most likely as wellmeaning or promising enthusiastic physician, although there are other possible interpretations. Of course, Gessner could not hide his identity for a long time, at least not in Zurich. The printer was his nephew Andreas Gessner, and Gessner personally dedicated a copy of the Thesaurus to his chief patron Heinrich Bullinger. ${ }^{32}$ Moreover, Gessner sent copies to his friends abroad, to Cosmas Holzach in the city of Schaffhausen and Johannes Kentmann in Saxony, ${ }^{33}$ and he also gave a copy to the Milan polymath Girolamo Cardano who was visiting Gessner in autumn 1552. ${ }^{34}$ Ten years later, in his letter to the English herbalist William Turner of 1562 where he is listing his publications, Gessner tries to justify why he had chosen a pseudonym. He pretends that his nephew Andreas who had recently become a printer had urged him to deliver the manuscript in an immature state, and that for this reason he had preferred to hide his true name. ${ }^{35}$ However, this is not convincing, the Thesaurus appears well-structured and meticulously executed down to the last details. One could at most imagine that Gessner originally had wanted to include more illustrations, a plan that was finally implemented in the German translation of 1555. The underlying reason for using an alias is rather obvious. Already at the time of writing of the Thesaurus the alchemical preparation of drugs was invariably tied to the Paracelsians, and under no circumstances did Gessner want be associated with them. Furthermore, there was an ambiguity about the word "secretum" in the title. For the contemporary reader, the first thought coming to mind must have been "secret", "hidden" or "covert", but Gessner wanted to understand it in the sense of "secreted" or "abstracted", as he writes in the argument following the title. According to him "remedii secreti" were remedies made by secretion through distillation or similar techniques (p. 2). But only a few pages later he surprises with the statement, "I have nothing, no matter how excellent or secret it might be, that I would not wish to communicate to the public" (p. 15), alluding to certain practitioners who tried to keep their knowledge private. In doing so, Gessner admits that he indeed had also

32 Zentralbibliothek Zürich, Md E 377.

33 Leu (2016), p. 313.

34 Salzmann (1956), p. 54-55.

35 Gessner (1562), f. $B_{1}$ r. 
secret remedies in mind he wanted to disclose. Whatever the case, the words of the title and the pseudonym radiated an aura of secrecy which certainly contributed to the success of the book.

In the preface Gessner sketches the history of alchemy as he knew it. He further admits that he is not versed in handling chemical devices, but that he nevertheless has gained some chemical knowledge from friends he is able to convey (p. 14). It is thus unlikely that he possessed his own laboratory equipment, the expense and the expenditure of time would have been too great for him, but he probably had visited the laboratories of pharmacies. The main text constitutes a comprehensive presentation of the procedures and products of medical alchemy, being mainly a compilation of different source texts, the authors of which are referenced by name. Further below this will allow us an exact analysis of the main sources. After defining distillation and introducing the necessary equipment, the part with the formulas is divided into three sections: distilled waters, distilled oils and other oily substances, and third formulas based on other modes of preparation than distillation. The first section discusses alcohol or brandy, followed by the notion of the quintessences made from plants, fruits, human blood, eggs, metals and the like. Among many other things Gessner gives recipes for rose water and for potable gold which always had played a predominant role in medical alchemy. Similarly, oils are distilled from plants, rubbers, resins (resulting for example in turpentine), woods, nuts, juniper berries, and so on. Considered as oils are also "oleum ex tartaro", the oily liquid (mainly solved potassium carbonate) resulting from dry distillation of tartar, and "aqua fortis", being highly concentrated acids which are distilled from vitriol or saltpeter. The book concludes with pressed oils, juices, medicinal wines, and other products which do not need to be distilled. Of the ten included illustrations three derive from Ulstad's distillation book. All the prescriptions in the Thesaurus are very clear and straightforward which is one more reason for its success. While the unchanged 1554 edition still upheld the pseudonym, ${ }^{36}$ Gessner finally lifted it in 1559. Only then was the front page exchanged to contain the addition "Euonymo Gesnero Philiatro authore", while the imprint still bore the year date 1554 of the former printing. This caused some confusion among scholars. The true date 1559 is displayed in an attachment consisting of a treatise by Jacobus Bessonus on the extraction of waters and oils from simple drugs. ${ }^{37}$ This fact is confirmed by Gessner himself in his letter to Turner, although he speaks of 1558, which may have been the year of the actual printing. ${ }^{38}$ The German translation Ein kostlicher theurer Schatz Euonymi Philiatri (Zurich 1555) contained twenty-six additional illustrations of distillation equipment. ${ }^{39}$ The success continued with repeated printings and translations at important centers of book production such as Lyon, Venice, and London.

36 See for example the copy of the Zentralbibliothek Zürich, Gal Tz 1050.

37 Gessner (1559), see for example the copy of the Bayerische Staatsbibliothek, M. Med. 355.

38 Gessner (1562), f. $\mathrm{B}_{1}$ r.

39 Gessner (1555d). 


\section{A Short History of Medical Alchemy}

It is difficult to trace back the very origins of alchemy, be they in India, China, Mesopotamia, or Egypt as most think. ${ }^{40}$ The first extant sources go back to Alexandrian Egypt and were passed on by way of Byzantine transcripts. The late Greek knowledge was taken over and enlarged by the Arabs who reached a high level of alchemy. ${ }^{41}$ Alcohol and the distillation of wine were known among Arabic alchemists as early as in the 8th century. ${ }^{42}$ The important Persian physician Abu Bakr arRazi (Rhazes, ca 864 - ca 925) wrote on practical alchemy including the preparation of drugs. ${ }^{43}$ Jabir ibn Hayyan (ca 721-815) who gave rise to the famous so-called Jabirian corpus of Arabic alchemy was not identical with the Geber of the Latin Middle Ages. The Summa perfectionis magisterii attributed to him was perhaps the most influential medieval treatise of technical alchemy and was also used by Gessner. ${ }^{44}$ Its true author was the Southern Italian Franciscan friar Paul of Tarent (13th century)..$^{45}$ The reception of alchemy in the West began only in the mid 12th century, when Arabic texts were translated into Latin. ${ }^{46}$ The technology of alchemy was quickly adapted, especially distillation and the distilling of alcohol for medical purposes. ${ }^{47}$ The encyclopedist Vincent of Beauvais (Vincentius Bellovacensis, ca 11901264) distinguishes in his Speculum doctrinale two kinds of alchemy, "ad fabrilem \& ad medicinam", one for craftsmen and the other for medicine, where the latter serves to separate possible poisons from the medicinal drugs. ${ }^{48}$ The eminent Italian surgeon Theodoric Borgononi (1205-1298) included in his textbook Cyrurgia sections on the distillation of the famous "oleum benedictum", the oil of bricks, on the sublimation of arsenic and the preparation of tartar oil. ${ }^{49}$ All of them were needed for the external treatment of wounds. This is the reason why alchemical preparations of balms, oils and the like were especially popular among barber surgeons. The Liber compostille by Bonaventura of Iseo (d. after 1273) constitutes a remarkable compendium of practical alchemy. ${ }^{50}$ It describes sophisticated varieties of distilla-

40 Davis (1936); Dubs (1947); Forbes (1953); Gantenbein (2011), pp. 119-123.

41 For an overview of Arabic Alchemy see Anawati (1996).

42 Levey (1960); al-Hassan (2009).

43 Taylor (2010).

44 Gessner used the edition Nuremberg 1541, see Gessner (1548), f. 173v.

45 Newman (1991).

46 Halleux (1996).

47 Lippmann (1923), pp. 56-136; Multhauf (1956); Gwei-Djen/Needham (1972); Rasmussen (2014).

48 Vincentius Bellovacensis: Spectrum doctrinale, Strasbourg ca 1477, book 12, chap. 105. See also Gantenbein (2011), pp. 123-124.

49 Cyrurgia (1498), f. 133v-134v. Gessner possessed this Venice print with a collection of Italian Medieval surgeons, see Leu et al. (2008), p. 136. In the Bibliotheca universalis, however, he recommended the 1499 edition, see Gessner (1545), f. 286r, 609r.

50 Gantenbein (2011), pp. 131-132. 
tion apparatuses with serpentine cooling tubes and water cooling in order to attain "aqua vite" (brandy, alcohol). The high-proof alcohol called "aqua ardens" is obtained by repeated distillation. Bonaventura further expounds a longer list of distilled waters for medical use, among which are also waters from metals and minerals. In the same vein, the founder of the Bologna school of medicine, Taddeo Alderotti (ca 1210-1295), remarked in his Consilia Medicinalia (ca 1280) on distilled alcohol and its medical applications. ${ }^{51} \mathrm{He}$ also prescribed for "aqua ardens" an up to tenfold distillation. Living at the same time, Roger Bacon (1214/1220-1292) called for an "ars experimentalis", an experimental science like alchemy to fathom the secrets of nature. According to him, alchemy had the capacity to make things which nature out of herself was not able to produce. In one respect he came astonishingly close to Paracelsus. Bacon postulated three ancillary disciplines for medicine, namely "philosophia”, "astronomia”, and "alchimia”. Taking into account that for Bacon the crowning of his "scientia integralis" were ethics and metaphysics, we arrive at an anticipation of Paracelsus's above mentioned famous four pillars of medicine. ${ }^{52}$ The most influential treatise of medical alchemy was the Liber de consideratione quintae essentiae omnium rerum of John of Rupescissa (d. after 1365). ${ }^{53}$ It introduces the notion of a medicinal "quintessence" which was expected to reside in all things. Similar to Bonaventura, distillation techniques and the preparation of "aqua ardens" are discussed. There is a whole spectrum of quintessences distilled not only from blood, meat, fruits, herbs, and roots, but also from metallic and mineral substances like gold, mercury, lead, tin, vitriol, iron, copper, sulphur, auripigment, and antimony. The treatise was handed down in numerous handwritten codices, whereas the tradition of the Liber de consideratio was mixed with the PseudoLullian corpus of alchemical tracts. ${ }^{54}$ So it was first printed under the title Sacri Doctoris Raymundi Lulii de secretis nature siue de quinta essentia (Augsburg 1518), whereas the first printing under Rupescissa's name was in Basle $1561 .{ }^{55}$ The next important step in the history of medical alchemy consisted of the books of the Strasbourg surgeon Hieronymus Brunschwig (ca 1450-ca 1512) who wrote in German. In the several revised editions of his Liber de arte distillandi he restricted himself first in 1500 to simple drugs, and finally ended up in 1512 with composite remedies. ${ }^{56}$ Various illustrations, which were endlessly copied by later authors, show the state of late medieval distillation technology. Although the distillation book of the erudite Nuremberg physician Philipp Ulstad was little more than an eloquent Latin plagia-

51 Giorgi/Pasini (1997), pp. 532-563; see also Gwei-Djen/Needham (1972), pp. 69-71, and Siraisi (1981), pp. 300-301.

52 Gantenbein (2011), pp. 124-128

53 Multhauf (1954), Halleux (1981), Gantenbein (2011), pp. 134-135.

54 Pereira (1989).

55 Gessner was well aware of the confusion, see Gessner (1552), p. 23.

56 For a description of the different editions of 1500, 1505, 1508, and 1512 see Gantenbein (2011), pp. 137-140. 
rism of Brunschwig, even the illustrations, it was more valued by Gessner. ${ }^{57}$ It was written in 1525 in the Swiss town Fribourg and printed in 1526 in Strasbourg under the title Coelum philosophorum, seu de secretis naturae liber (heavens of the philosophers, or book of the secrets of nature).$^{58}$ It went through over twenty editions. ${ }^{59}$

According to the extensive entry in the Pandects, Gessner showed a keen interest in scholarly alchemy. ${ }^{60}$ In the Thesaurus (1552) he outlined the history of "chymia". He thinks that it was first practiced in the regions where the "Punic or Arabic language" was spoken (p. 6), hinting at the original Arab region of the Middle East and the area of the former Carthaginian Empire with Northern Africa and Southern Spain. As a time span for the emergence of alchemy he posits "a little later than the time of the Greek physicians” (p. 6), and indicates representatives of this transition period, namely the Alexandrian and Byzantine physicians Oribasius (ca 320-403), Aetius of Amida (6th century), Michael Psellos (1017/18-1078) and Johann Zacharias Actuarius (1275-1328). This covers exactly the period when Greek and Arabic alchemy were flourishing. Gessner recounts that in Italy he had seen Greek alchemical manuscripts, one of Stephanos of Alexandria (around 600) and another one about the transmutation of metals. Then he mentions a Pseudo-Avicennian "alchymia ad Assem philosophum"61 and extols the Summa perfectionis of (Pseudo-) Geber which describes the various modes of distillation (p. 7). Further he gives little credence that Aristotle, Plato, and Solomon were the true authors of certain treatises. He doesn't deny the existence of potable gold and the philosopher's stone. Moreover, he is convinced that it is possible to extract a shining liquid out of fireflies or other bright things (p. 10-11). Gessner knows that in Moorish Spain many erudite books were translated from Arabic into Latin. Of the Moorish physicians he esteemed above all Abulcasis or with his Arabic name Abu l-Qasim Chalaf ibn al-Abbas azZahrawi (936-1013), whom he also called Bulcasis (p. 11). Besides the famous illustrated surgical books, Abulcasis had also written the Liber servitoris which relies heavily on medical alchemy. Gessner had access to the Venice edition of PseudoMesue (1485) which also handed down the Liber servitoris. ${ }^{62}$ The medical and pharmaceutical corpus of the Latin Mesue has little to do with the two Nestorian physicians Abu Yuhanna Masawaih and his eponymous son Yuhanna Ibn-Masawaih

57 Gessner's personal copy of the 1535 edition is preserved in the University Library of Basle and contains many handwritten annotations, see Leu et al. (2008), p. 244.

58 Many scholars confounded the Swiss town Freiburg in Üchtland or Fribourg with the German Freiburg in Breisgau, or they even thought that Fribourg was the printing place. However, Ulstad writes in the preface of the first edition of Strasbourg 1526: "Ex Friburgo Heluetico viij. Kalen. Maias, Anno a Christo nato DDD.XXV".

59 Atkinson/Hughes (1939).

60 Gessner (1548), f. 173v-174v.

61 Likewise in Gessner (1545), f. 110r; Gessner (1548), f. 173v.

62 Leu et al. (2008), p. 148; he possibly also knew the edition of the Liber servitoris in Sylvius (1549) as indicated by his handwritten entry in Gessner (1545), f. 20v. 
(ca 777-857), Latinized Ioannes filius Mesue. ${ }^{63}$ The Antidotarium Mesue (13th century), also called Grabadin, remained for centuries the most authoritative textbook of pharmacology. For practical purposes Gessner used above all the Mesue commentaries of the French physician Jacobus Sylvius (Jean Dubois, 1478-1555) and of the two Minorite monks Brother Angelus Palea Iuvenatiensis (of Giovinazzo) and Brother Bartholomaeus Urbevetanus (of Orvieto), calling the latter "Monachorum Commentarii in Mesuen” (p. 22). ${ }^{64}$ Apparently leaning on the monks' commentary, Gessner remarks that Mesue only knew distilled waters from roses and wormwood (p. 12), ${ }^{65}$ and goes on to say that Avicenna also knew rose water. The sublimation of metals and the distillation of oils "per descensum" as described by Rhazes and Actuarius is, in his view, far older (p. 12). ${ }^{66}$ Moreover, Gessner does not believe that the later Greeks were able to distill liquors as "recently someone has written whose name I spare myself". ${ }^{67}$ This ominous remark again hints at Paracelsus, who had left his manuscript of De gradibus et compositionibus with Clauser, where one finds the corresponding passage: "I do not deny how much Platearius, Dioscorides, Serapio and their followers here dissent who have not a little written about the quintessence, but falsely." 68 This episode proves once more that Gessner kept a sharp eye on the Paracelsian tradition.

\section{The cited sources in the Thesaurus of 1552}

The main text of the Thesaurus is preceded by a list with the names of 43 authors who are going to be used. In fact, Gessner is referring to an additional number of around 30 authors giving a total of around 70 cited authors. Every entry is faithfully followed by the name of the source. This offers the possibility of creating a statistic to identify the principal sources. The following table contains the main sources of the Thesaurus in decreasing order of their citation frequency. They will afterwards be discussed separately. The third column specifies the corresponding works as indicated by Gessner.

\footnotetext{
63 Schmitz (1998), pp. 244-248; De Vos (2013).

64 Sylvius (1542a) resp. Pseudo-Mesue (1543).

65 See Pseudo-Mesue (1543), p. 43, section D, and p. 162, section L.

66 The "destillatio per descensum" is described by Gessner (1552), pp. 319-322, following Ulstad (1535), f. 21v-22r.

67 “Nuper quidam scripsit, cuius nomini parco", Gessner (1552), p. 12.

68 "Non enim ignoro, quantum ab hoc loco dissentiant Platearius, Dioscorides, Serapio, caeterique qui hos sunt sequuti, qui non pauca de Quinta Essentia scripserunt, sed falso.” Paracelsus/Huser, vol. 7, p. 19.
} 


\begin{tabular}{lll}
\hline $\begin{array}{l}\text { Fre- } \\
\text { quency }\end{array}$ & Author & Relevant Works \\
\hline 60 & Jacobus Sylvius (Jean Dubois, 1478-1555) & Sylvius (1541, 1542, 1542a) \\
\hline 49 & Girolamo Cardano (1501-1576) & Cardano (1550), Forrester (2013) \\
\hline 49 & Pseudo-Lullius (14th century) & Pseudo-Lullius (1541) \\
\hline 46 & Philipp Ulstad (16th century) & Ulstad (1535) \\
\hline 38 & Arnoldus of Villanova (ca 1235-1311) & Villanova (1504) \\
\hline 38 & Abulcasis (936-1013) & Pseudo-Mesue (1485), Sylvius (1549) \\
\hline 35 & Walther Hermann Ryff (ca 1500-1548) & Ryff (1545) \\
\hline 28 & Pseudo-Mesue (13th century) & Pseudo-Mesue (1485), Sylvius (1542a, \\
\hline 24 & Hieronymus Brunschwig (ca 1450-ca 1512) & Brunschwig (1500, 1512) \\
\hline 18 & André Le Fournier (Furnerius, 16th century) & Le Fournier (1533) \\
\hline 12 & Pseudo-Roger Bacon & “quem manuscriptum habeo” (p. 200) \\
\hline
\end{tabular}

By far the most citations in the first Thesaurus concern the French physician and anatomist Jacobus Sylvius (1478-1555). Gessner refers to his Methodus medicamenta componendi (1541) and his commentary on Pseudo-Mesue of $1542 .{ }^{69}$ Gessner must have valued Sylvius's erudite and systematic writing style which covered every detail of the subject. We are fortunate that the former and another work of Sylvius on simple remedies are extant which had belonged to Gessner's private library. ${ }^{70}$ They both contain sections on distillation and distillation products which Gessner had heavily annotated. They offer the unique opportunity to observe his methodical approach in writing a book. He subdivided the various source texts into individual paragraphs and marked them with curly brackets. Then he ordered the excerpts thematically and assigned them to the intended chapters. As the following examples show, Gessner took over the text more or less literally with only minor adaptations. In this way he extracted from Sylvius (1542), f. 26v, the definition of distillation, "DESTILLATIO humoris e succo tenuoris extractio vi caloris", and put it at the very beginning of his main text: "DESTILLATIO (ut doctiores scribunt, non distillatio) est humoris e succo tenuiores extractio vi caloris, Sylvius” (p. 25), only adding that the

69 Sylvius (1542a).

70 Sylvius $(1541,1542)$ in the Zentralbibliothek Zürich, Md A 29 4 and Md A 29 respectively, see Leu et al. (2008), p. 108. 
scholars prefer "destillatio" in place of "distillatio" and correcting the "tenuoris" to “tenuiores”. Leaving some lines out, Gessner then quotes Sylvius's definition of the usual mode of distillation with ascending vapors, "etiam de destillatione per ascensum, sic dicta, quod vapores sursum elati, ibi concreti, in aquam destillent”, which becomes in the Thesaurus: "Destillatio per ascensum dicitur, ubi vapores sursum elati, ibi concreti in aquam destillant, Idem." Many longer paragraphs are even adopted verbatim, for example the one about the water bath from Sylvius (1541), p. 170: "Praeterea aquae ferventes, aut ab his vapor mitius agunt ... per os eiusdem praelongum destillat", which becomes in Gessner: "Aquae ferventes aut ab his vapor minus agunt ... per os eiusdem praelongum destillat, Sylvius” (pp. 46-47, see Fig. 1 and 2). Gessner even marked in the source the location where he wanted to insert a new paragraph. In some cases, he gave also a Latin translation, for example he rendered Mattioli's extensive Italian recipe for scorpion oil. ${ }^{71}$

Just as in Sylvius, Gessner also appreciated the scholarship of the Italian polymath Giffrolamo Cardano (1501-1576). In his most influential work De subtilitate, first published in 1550, Cardano had tried to expound the core aspects of natural philosophy. ${ }^{72}$ Gessner took excerpts from the chapters on the four elements, the metals, and the plants which contained sections on alchemy and distillation. Proceeding to the next source text, Gessner often cites the print De secretis naturae sive de quinta essentia by Pseudo-Lullius. In the Bibliotheca universalis he refers to the edition Nuremberg $1541 .{ }^{73}$ As mentioned above, the core part of De secretis naturae consists of Rupescissa's Liber de consideratione quintae essentiae (14th century) which constitutes the most important text of medieval medical alchemy. Many Renaissance physicians possessed manuscript versions of the Consideratio in their private libraries, as was also the case with Christoph Clauser. ${ }^{74}$ Gessner also used a Liber de aquis by Pseudo-Lull which is part of the manuscript tradition. As the handwritten marginal addendum in his personal copy of the Bibliotheca universalis proves, Gessner put great value on Hieronymus Brunschwig's (ca 1450-ca 1512) destillation books, which were published between 1500 and 1512: "Hieronymus Brunsuicensis primus de destillandis liquoribus uoluminem utilissimum Germanice scripsit” (H. B. first wrote in German a most useful book about the distillation of liquors). ${ }^{75}$ They were indeed the first printed books which elaborated the technical details of distillation. ${ }^{76}$ Gessner possessed of Philipp Ulstad's (16th century) Latin adaptation of Brunschwig the 1535 edition which is preserved at the University Li-

71 Mattioli (1548), book 6, f. 17; Gessner (1552), p. 507-511.

72 See Fierz (1983), especially pp. 88-116, and the introduction in Forrester (2013).

73 Gessner (1541), f. 579v.

74 On manuscript collections of medical alchemy see Gantenbein (2011), pp. 140-143, on Clauser see Heyne (2002), pp. 45-46, 70, 72-73.

75 Zentralbibliothek Zürich, DrM 3, f. 327v.

76 The rudimentary incunabula of Michael Puff of Schrick on the use of various distilled waters, appearing since 1478 in several editions, gave no technical instructions. 


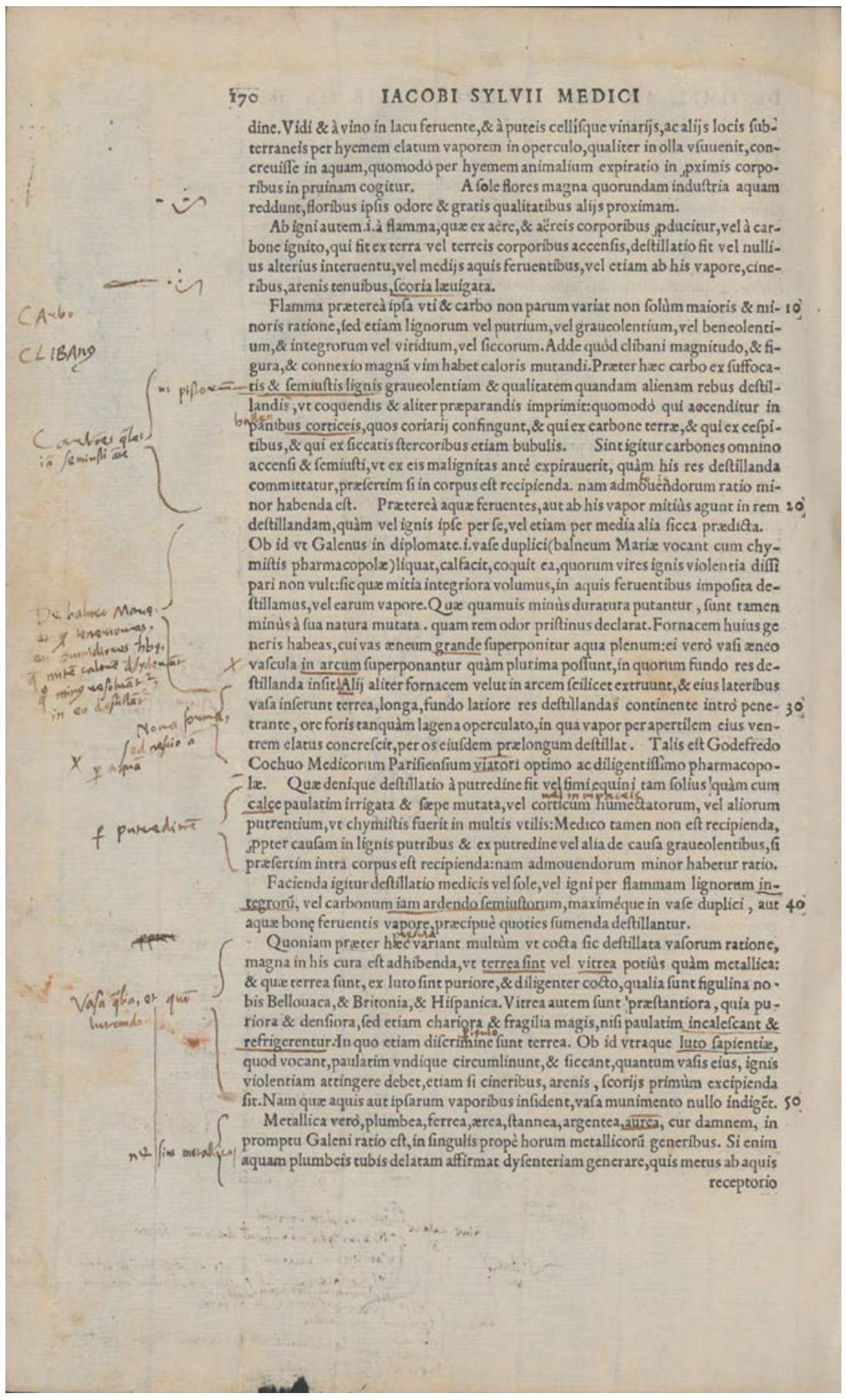

Fig. 1: Section on the “Balneum Mariae” in Sylvius (1541), p. 170, lines 20-32, with Gessner's annotations (ZBZ, Alte Drucke und Rara, Md A 294). 


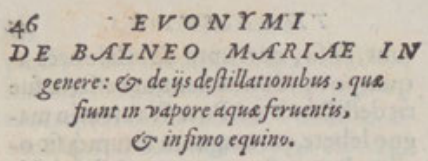

- Qux feruentes aut ab his uapor minus agunt in rem deftillandá, ఫิuelignisipfe perfe, uel etiáper media alia ficca prędicta.Obid ut Galenus in diplomate, id eftuafe duplici (balneú Mariæu uocát cú chymiftis pharmacopolx)liquat, calfacit, coquit ea, quorŭ uires ignis uiolentia difsipari nó uult: fic qux mitia integriora uolumus, in aquis feruentib.impofita deftillam, uel carú uapore. Qux quáuis minus duratura putátur,funt tamé minus à fua natura mutata:quam rem odor priftinus declarat.

Fornacéhuiusgeneris habeas, cui uas æeneú grăde fuperponí̌ aqua plenú: è uerò uafi æneo uafcula in arcú fuppo* nátur g̃plurima poffunt, in quorú fun dores deftilläda infit. Alij aliter forna-

cem
THESAVRVS. $\quad 47$ cé,uelut in arcéf filicet extruút, \& cius lateribus uafa inferút terrea, longa, fun dolatiore deftillanda continéte, intrò penetráte, ore foris tanq̄ lagena operculato, in qua uapor per aptilem eius uentrem elatus concrefcit, per os ciufdem pralongum deftillat,Syluius.

Sed curodor florú quorundã nó reti netur in aquis, uerum ut in iafmino \& caryophyllo flore ac lilio aqua euadit odoris exps?dictú eft alibi: quoniă tá tenuifubrtátiæ nulla pars cralsioriungit.Ergo in hisiuuabit; fi folijs herbarú quę odore carcát alternati pofitis materię crafsiori,nó tamé quę urát, adiun gat odor, inde deftillet. ato ipes pliciédi odoris, cú aquis infufa nó remittất odoré,fed putref́cát, Cardan. Apparet aút hos flores pculdubio in balneo M.aut in aqux feruentis uapore uafis uitreis deftillari oportere.

Balneum M. commoded calfit cum amplo canali è cupro in medium imif fo, in cuius imo craticula eft, ut cineres defluát: uulgus pigrum Henricum

Fig. 2: "Balneum Mariae” in: Gessner (1552) as taken from Sylvius (ZBZ, Alte Drucke und Rara, Md E 377).

brary of Basle. ${ }^{77}$ Again, it contains many of his annotations. Next in the list is the Catalan physician Arnoldus of Villanova (ca 1235-1311) who wrote numerous works on medicine and pharmacy. Gessner recommended his collected works from the edition of Lyon 1504. In the Thesaurus he leans on Villanova's treatises Liber de vino on medicinal wines, his De conservanda iuventute on the preservation of youth, his Breviarium, his Antidotarium, and his De viribus aquae vitae on the medical use of alcohol, whereas the latter is probably pseudepigraphic as are most of the works on alchemy attributed to him. ${ }^{78}$ Walther Hermann Ryff (ca 1500-1548) published in 1545 his comprehensive New groß Distillier Buoch. Besides the description of plants it contained numerous novel illustrations of sophisticated distillation apparatuses which meant a technological leap in comparison to Brunschwig and Ulstad. Many subsequent herbal books plagiarized their figures of distillation apparatuses from Ryff. André Le Fournier (Furnerius, 16th century) was a Parisian physician and lec-

77 Leu et al. (2008), p. 244.

78 See McVaugh (2005). 
turer on medicine about whom little is known. ${ }^{79}$ He had written a book in French on cosmetic formulas for which he used distillation products. Furthermore, Gessner possessed a manuscript on distilled waters which he ascribed to (Pseudo-) Roger Bacon. ${ }^{80}$ Together with Pseudo-Mesue the pharmacopeia De materia medica of the Greek physician Pedanius Dioscorides of Anazarbus (first century) belonged to the most authoritative texts of pharmacology. The Italian physician Pietro Andrea Mattioli (1501-1577) wrote an extensive commentary on Dioscorides which went through numerous editions. Gessner used for the first Thesaurus one of the Italian editions (1544, 1548, or 1549), whereas the first Latin edition appeared only in $1554 .{ }^{81}$ Gessner had resorted to Mattioli because the latter had interspersed passages on distillation. A separate annex on distillation with a few illustrations was included for the first time in the 1565 Latin edition. Moreover, Gessner exploited another publication of Mattioli, his Latin treatise of 1533 on syphilis in which he described an "aqua philosophica" and the oil from guaiac wood. ${ }^{82}$ Besides all this, the pharmacology of Pseudo-Mesue, be it in the commentaries of Sylvius or of the "monachi", still played an important role in Gessner's medical thinking.

\section{The second Thesaurus of 1569 and Caspar Wolf}

In his letter to William Turner of September 5, 1562, three years before his death, Gessner had uttered the intention to revise his Thesaurus: "I plan to give something more perfect if God gives me the lifetime". ${ }^{83}$ Fully concerned with editing his naturalist books and his obligations as a town physician, Gessner unfortunately had no time for this endeavor. Shortly before his death, Gessner sold his private library and his scientific estate to his successor as a town physician of Zurich, Caspar Wolf $(1532-1601) .{ }^{84}$

In order to ensure his legacy, Gessner had trained Wolf for many years. He had even supported a scholarship for Wolf's medical studies at Montpellier and other French universities. ${ }^{85}$ Wolf proved himself a worthy and capable disciple. Although he did not succeed in the enormous task of completing Gessner's history of plants, he ordered his extensive recipe collection and published a whole series of his drafts

79 Clair et al. (1995).

80 Gessner (1552), pp. 24, 200.

81 Mattioli's Discorides commentary is not mentioned in Gessner (1545).

82 Mattioli (1533).

83 "Et aliquando absolutiorem dare cogito, si Deus vitam dederit", Gessner (1562), f. B $\mathrm{B}_{1}$.

84 Fischer (1966), pp. 134-142; Leu et al. (2008), pp. 5-9; Leu (2016), p. 382.

85 See Zentralbibliothek Zürich, Ms. L 409. Wolf studied 1552-1555 in Basle, Paris, and Montpellier, was graduated in 1557 in Orléans, and continued his studies in 1558 in Padua, see Marti-Weissenbach (2013). His doctor's diploma is still in private possession of the Wolf family. 
and the scientific correspondence. ${ }^{86}$ These activities also included the emendation of the first Thesaurus (from now on called Thesaurus I). The outcome consisted of the "pars secunda", the second part of the Conradi Gesneri Medici et Philosophi Tigurini Euonymus, sive de Remedijs secretis (1569). According to this title, the full credit of authorship of the Thesaurus II is given to Gessner, whereas in the subtitle Wolf figures only as an eager editor. The following analysis will render quite a different picture. A superficial look at the Thesaurus II might suggest that besides an enriched set of illustrations not much had changed. As in the Thesaurus $I$, the four parts concern general remarks on distillation, waters, oils, and special products. A few remedies were allocated to other sections. For example the "aurum potabile" was now shifted from the waters to the fourth part. The true difference only becomes apparent when again the list of the most cited authors is created:

\begin{tabular}{lll}
\hline Frequency & Author & Relevant Works \\
\hline 35 & Antonio Fumanelli (d. ca 1548) & Fumanelli (1548) \\
\hline 26 & “ex litteris ad Gesnerum” & \\
\hline 19 & Leonardo Fioravanti (1517-1588) & Fioravanti (1561) \\
\hline 15 & Gabriele Falloppio (1523-1562) & Falloppio (1563, 1564) \\
\hline 15 & Theophrastus Paracelsus (1493/94-1541) & \\
\hline 12 & Pseudo-Roger Bacon (Rogerius) & Villanova (1504) \\
\hline 9 & Arnoldus of Villanova (ca 1235-1311) & \\
\hline 7 & Conrad Gessner (1516-1565) & Langius (1554) \\
\hline
\end{tabular}

The first striking point in comparison to Thesaurus I is the fact, that in Thesaurus II relatively few authors are mentioned, although the two works are roughly the same size. The main reason is that Wolf had often transcribed from manuscripts or had added various recipes, the authors of which were probably unknown to him. Then it must be noted that most of the prominent authors of the Thesaurus I are totally absent or play only a minor role in Thesaurus II. Sylvius and Cardano, whom Gessner had greatly appreciated, have now completely disappeared, and the same is true for Pseudo-Mesue and the line of tradition from Pseudo-Lullius and Brunschwig to Ulstad. Only Villanova and Pseudo-Roger Bacon remained, the latter because Wolf had inherited the corresponding manuscript. On the other hand, Wolf shows a clear preference for Italian authors. The most cited one is Antonio Fumanelli who

86 Leu (2016), pp. 379-384. 
had written a Latin treatise on the composition of medicaments. Behind the unsuspecting title De compositione medicamentorum (Venice 1548) is hiding, however, a most remarkable work on alchemically prepared remedies which could even be regarded as a certain predecessor of the Thesaurus $I$. There are sections on distillation and on various distillation products with their medical applications. The book must have escaped Gessner's attention. The Bologna physician Leonardo Fioravanti (1517-1588) landed with his Capricci medicinali (Venice 1561, in other editions titled Secreti medicinali) a success that equaled the one of the Thesaurus $I$. When in 1558 Wolf was completing his medical studies in Padua, he must have met there the famous surgeon and anatomist Gabriele Falloppio (1523-1562) who taught at the university. Falloppio had written two books referenced by Wolf, one on medical and alchemical secrets and the other on spas and metals. ${ }^{87}$ Wolf also relates to the correspondence of Johannes Langius (1485-1565) who was personal physician of the Elector Palatine. In his first book of letters of 1554, Langius had extensively commented on alchemy and distillation. ${ }^{88}$ Since Wolf was in possession of the entire correspondence of Gessner, the second most frequent quotes in Thesaurus II derive from the received letters. In certain cases Gessner is actually cited as an individual source. Several interspersed recipes originate from Wolf's colleagues whom he calls by name. Additionally, he has "newly received" (accepi nuper) from his Basle colleague Felix Platter a drawing of a special distillation apparatus which is most useful for the extraction of oils. ${ }^{89}$ After Gessner's almost anxious avoidance of Paracelsus, Wolf finally cites him freely and without any polemics. The corresponding recipes relate to various external balsams for surgical purposes, further to "oleum saturni”, "oleum a bolo armeno”, salts and "alkali”, an "aqua vitae” for fevers, and eventually to "oleum antimonij which Theophrastus Paracelsus held as a secret". 90 The attractiveness of the Thesaurus II was further enhanced by around forty illustrations, whereby about half of them were gleaned from Ryff and the book on fire technology by Vannoccio Biringuccio, called Pirotechnia (first edition in Venice 1540). So half of the distillation equipment depicted in Dobler's inaugural dissertation which he ascribed to Gessner actually originate from earlier sources. ${ }^{91}$ Furthermore, there is a distinctive difference in the writing style. Whereas in the Thesaurus $I$ the prescriptions are straightforward and well suited for beginners, the Thesaurus II with its complicated apparatuses and its demanding procedures which require many weight specifications is rather meant for experienced professionals. Summing up, this treatise is by no way a second part of the Thesaurus I, but rather

87 Falloppio (1563); Falloppio (1564).

88 Langius (1554), pp. 199-206.

89 Gessner (1569), f. 73v.

90 The citations concerning Paracelsus are found in Gessner (1569), f. 91v, 93r, 101r, 104r, 137r, 175rv, 195v, 199r, 205r, 212r, 213v, 214v, and 229v.

91 Dobler (1995). 
a second, totally revised edition based on different sources. It is as if the same book was written twice, only with different sources. There is no indication that Gessner had left any draft for this new book. The actual author of the Thesaurus II must be Wolf who acted according to his own predilections and abilities. This is corroborated by the fact that he speaks of Gessner always in third person as if he were an independent source. Taking further into account that the Thesaurus II not only contains longer sections on antimony, vitriol, and potable gold, but is also quoting Paracelsus by name, it can be concluded that Wolf was deeply steeped in the Paracelsian tradition. The reason for paying full tribute to Gessner may not only have been modesty, but also a hoped-for economic advantage in the wake of the extremely successful Thesaurus I. Undertaken by the Zurich physician Johann Jacob Nüscheler, the Thesaurus II underwent a German translation in 1583, with a second edition in $1608 .^{92}$

Only two years before the Thesaurus II, Wolf had published another work on medical alchemy. He called it Polychymia (1567). ${ }^{93}$ Like the two Thesauri, it was subdivided into four parts, namely the sections on waters, oils, salts, and special preparations. Within the sections the individual preparations are consecutively numbered, for example in section three we read the titles 1. De sale communi, 2. De artificiosa salis praeparatione, 3. Sal urinae, 4. Sal Alkali, 5. Sal Cinerum, 6. Sal Calcis vivae, and so on. The subdivision into waters, oils, and salts calls to mind the Paracelsian Tria Prima consisting of mercury, sulfur, and salt, but not only that. The above mentioned Medieval Liber compostille by Bonaventura of Iseo, which Clauser had copied in 1508 in Pavia, ${ }^{94}$ shows exactly the same subdivisions. Already a cursory comparison of the Polychymia with the Munich manuscript of the Liber compostille $^{95}$ reveals striking similarities. Although using different wordings, there are partly the same formulas and some of them are even written in the same order. The corresponding headings read here as follows: 1. Sal commune, 2. Sal urine, 3. Sal alkali, 4. Sal cineris, 5. Sal calcis vivi, and so on. Further research must be done, but undoubtedly the Polychymia constitutes another version of the Liber compostille. Wolf states that his manuscript was very corrupted, ${ }^{96}$ so it probably doesn't directly correlate with Clauser's copy. Like Gessner, Wolf published the Polychymia anonymously under the pseudonym "Diodorus Euchyons", but already in the Thesaurus II he lifted the veil and writes of the "Polychyima Diodori Euchyontis which was edited by us". ${ }^{97}$ His authorship was also confirmed in the much expanded third

92 Gessner (1583).

93 There is a brief description of the Polychymia in Büchi (1984), pp. 193-195. Otherwise it was not studied yet.

94 Heyne (2002), pp. 94-95.

95 Bayerische Staatsbibliothek, Clm 23809. A critical edition of all the known versions is lacking.

96 Wolf (1567), f. A6r.

97 Gessner (1569), f. 35r. 
edition of the Bibliotheca universalis (1583). ${ }^{98}$ Besides these editions, Wolf also worked as an independent author. This is evident from his literary estate which is kept in the Sloane Collection of the British Museum. ${ }^{99}$ Among lecture notes from the Paris stay in 1553 and other items, there are several successive manuscripts of an Antidotarium Practicum Novum in five books. Written in the years 1598-1600 and covering all kinds of illnesses from head to toe, this extensive work was meant as a help for the practicing physician. The Antidotarium is completed by a treatise on the plague, other epidemics, and contagion, and further a special Theriacographia. Clearly arranged and neatly written, these manuscripts again convincingly document Wolf's pharmaceutical expertise. They were obviously meant for publication, only thwarted by his death in 1601 .

\section{Epilogue: Paracelsus wins the race}

In the long run, Paracelsianism prevailed over Galenism. The chemical remedies eventually became an integral part of the official pharmacology. Based on the same medieval tradition of alchemy as Paracelsus, Gessner had tried to give an alternative representation of the subject. At first biased under the sway of Bullinger and Clauser, in the Thesaurus I (1552) he had avoided every mention of Paracelsus. Nevertheless, it was possible to identify two formulas of Paracelsus and an indirect reference to one of his treatises. Gessner's writing method consisted in selecting individual sections from various source texts and assigning them to the separate thematic chapters. In this way most of the "secrets" in the Thesaurus I had already been printed elsewhere, and if not, they derived from "empirici” or Paracelsians. Gessner's own chemical achievements were certainly overrated by Friedrich Dobler in his inaugural dissertation Conrad Gessner als Pharmazeut (1955). Dobler, however, was a pioneer in the experimental verification of historical formulas from Gessner and Paracelsus. ${ }^{100}$ The real author of the more technical Thesaurus II (1569) was Gessner's successor Caspar Wolf who had a wide range of materials at his disposal which he handled with great expertise. Wolf relied in this revised book on completely different printed sources than Gessner. Due to the selection of topics and because of the frequent mention of Paracelsus, the Thesaurus II comes very close to the Paracelsian tendency of that time. The Polychymia (1567) as edited by Wolf, could be identified as a version of the Medieval Liber compostille by Bonaventura of Iseo, which in turn may be seen as an early precursor of the two Thesauri.

98 Gessner (1583a), p. 260.

99 British Museum, Sloane Mss. 3036-3046.

100 Dobler (1955). I knew Dobler personally, see Gantenbein (2000) with references to further results from Dobler. 